\title{
PENGARUH CORPORATE GOVERNANCE TERHADAP MANAJEMEN LABA PADA PERUSAHAAN JASA DI INDONESIA
} (STUDI KASUS PADA PERUSAHAAN JASA YANG TERDAFTAR DI BURSA EFEK INDONESIA TAHUN 2005-2007)

\begin{abstract}
Purpose of this research is to find the empirical proof that the board composition, board size, the existence of audit committees, company size and managerial ownership affects some earnings management. With Corporate Governance in the company are expected to affect corporate earnings management actions.

This research uses the entire population of IDX services company in the year 2005-2007, using purposive sampling techniques sampling the sample obtained by 25 companies. The results using multiple regression analysis is the composition of the board of commissioners, the overall effect of revenue management. This is evidenced by the significance value of $0.002<0.05$. Board size effect on earnings management. This is evidenced by the significance $0.018<0.05$. Audit committees have no effect on earnings management .. This is evidenced by the significance $0.236>0.05$. Size does not affect the company's revenue management, as evidenced by the value of significance $0.222<0.05$. Managerial ownership has no effect on earnings management, as evidenced by the significance value of $0.581>0.05$.
\end{abstract}

Keywords: Composition of the Board of Commissioners, Board Size, Existence of Audit Committee, Company Size, Managerial Ownership and Earnings Management

\section{PENDAHULUAN}

Laporan keuangan tidak lagi secara objektif menginformasikan apa yang telah dilakukan dan dialami perusahaan, sebab aktivitas rekayasa manajerial ini dimanfaatkan manajer untukmenyembunyikan kecurangankecurangan yang pernah dilakukannya. Laporan keuangan merupakan media pertanggungjawaban manajer kepada stakeholder perusahaan. Manajer menggunakan laporan keuangan untuk mempertanggungjawabkan semua transaksi dan kejadian yang telah dilakukan dan dialami selama satu periode tertentu.

Akhir-akhir ini laporan keuangan telah menjadi isu sentral, sebagai sumber penyalahgunaan informasi yang merugikan pihak-pihak yang berkepentingan. Pada tahun 1998 sampai dengan 2001 tercatat telah terjadi banyak skandal keuangan di perusahaan-perusahaan publik dengan melibatkan persoalan laporan keuangan yang pernah diterbitkannya. Beberapa kasus yang terjadi di Indonesia, seperti PT. Lippo Tbk dan PT. Kimia Farma Tbk juga melibatkan pelaporan keuangan (financial reporting) yang berawal dari terdeteksi adanya manipulasi. Salah satu penyebab kondisi ini adalah kurangnya penerapan corporate governance. Bukti menunjukkan lemahnya praktik corporate governance di Indonesia mengarah pada definisi pembuatan keputusan dalam perusahaan dan tindakan perusahaan.

Informasi laba sebagai bagian dari laporan keuangan, sering menjadi target rekayasa melalui tindakan oportunis manajemen untuk memaksimumkan kepuasannya, tetapi dapat merugikan pemegang saham atau 
investor. Tindakan oportunis tersebut dilakukan dengan cara memilih kebijakan akuntansi tertentu, sehingga laba perusahaan dapat diatur, dinaikkan atau diturunkan sesuai dengan keinginannya. Perilaku manajemen untuk mengatur laba sesuai dengan keinginannya tersebut dikenal dengan istilah manajemen laba (earnings management ). Tujuan Earnings Management adalah meningkatkan kesejahteraan pihak tertentu walaupun dalam jangka panjang tidak terdapat perbedaan laba kumulatif perusahaan dengan laba yang dapat diidentifikasikan sebagai suatu keuntungan.

Banyak peneliti yang meneliti tentang pengaruh corporate governance terhadap manajemen laba salah satu nya, penelitian Midiastuty dan Machfoedz (2003) menyatakan bahwa ukuran dewan komisaris berpengaruh secara signifikan terhadap indikasi manajemen laba yang dilakukan oleh pihak manajemen. Pengaruh tersebut ditunjukkan dengan tanda positif. Hal tersebut berarti makin besar ukuran dewan komisaris maka makin banyak manajemen laba yang dilakukan oleh perusahaan. Dari sini dapat disimpulkan bahwa jumlah komisaris yang lebih sedikit lebih mampu mengurangi indikasi manajemen laba daripada jumlah komisaris yang banyak.

Dari pengujian Veronica dan Utama (2005) dalam Rahmawati \& Baridwan (2006) dilaporkan variabel yang berpengaruh signifikan terhadap besaran manajemen laba adalah ukuran perusahaan. Makin besar ukuran perusahaan, makin kecil tindak manajemen labanya. Rahmawati dan Baridwan (2006) menunjukkan bahwa ukuran perusahaan yang diukur dengan menggunakan kapitalisasi pasar berpengaruh signifikan positif terhadap manajemen laba perusahaan. Ini menunjukkan bahwa manajer perusahaan besar mendapat insentif yang lebih ketika dia melakukan manajemen laba demi mengurangi kos politisnya

Penelitian ini menguji mekanisme corporate governance: komposisi dewan komisaris, ukuran dewan komisaris, keberadaan komite audit, ukuran perusahaan, dan kepemilikan manajerial terhadap praktik manajemen laba yang dilakukan di perusahaan jasa di Indonesia. Dalam mendeteksi manajemen laba menggunakan model Jones, merupakan model yang lebih baik dibanding model time-series. Dalam model ini Total Accrual diestimasi dengan model cross-sectional Jones Model sebagai fungsi property, plant, dan equipment (PPE), serta perubahan pendapatan dan piutang bersih.

\section{TELAAH LITERATUR DAN PENGEMBANGAN HIPOTESIS}

\section{Komposisi Dewan Komisaris dan Manajemen Laba}

Beasley (1996) menyarankan bahwa masuknya dewan komisaris yang berasal dari luar perusahaan meningkatkan efektivitas dewan tersebut dalam mengawasi manajemen untuk mencegah kecurangan laporan keuangan. Hasil penelitiannya juga melaporkan bahwa komposisi dewan komisaris lebih penting untuk mengurangi terjadinya kecurangan pelaporan keuangan, daripada kehadiran komite audit. Analisis lain dalam penelitian ini menunjukkan bahwa karakteristik komisaris yang berasal dari luar perusahaan (outsider director) juga berpengaruh terhadap kecenderungan terjadinya kecurangan pelaporan keuangan. Dari beberapa penelitian di atas maka hipotesis dalam penelitian ini adalah:

$\mathrm{H}_{1}$ : $\quad$ Komposisi Dewan Komisaris berpengaruh terhadap Manajemen laba 


\section{Ukuran Dewan Komisaris Berpengaruh Terhadap Manajemen laba}

Terkait manajemen laba, ukuran dewan komisaris dapat memberi efek yang berkebalikan dengan efek terhadap kinerja. Hal ini bisa dimengerti karena sesuai dengan pernyataan Scott (2000) bahwa melakukan manajemen laba dapat dilaksanakan dengan berbagi cara salah satunya menurunkan laba (income decreasing earnings management).

Hasil yang sejalan dengan Yermack 1996, Eisenberg, Sundgren, dan Wells 1998, dan Jensen 1993 dalam Beasley (1996) yang melaporkan bahwa pengaruh ukuran dewan komisaris terhadap kecurangan dalam pelaporan keuangan adalah positif secara signifikan. Untuk itu penelitian ini mendukung bahwa dewan komisaris yang lebih banyak kurang efektif dalam melakukan pengendalian terhadap manajemen. Dari Penelitian diatas maka hipotesis dalam penelitian ini adalah:

$\mathrm{H}_{2}$ : $\quad$ Ukuran dewan komisaris berpengaruh terhadap manajemen laba

\section{Komite Audit dan Manajemen Laba}

Sesuai dengan Kep. 29/PM/2004, yang merupakan peraturan yang mewajibkan perusahaan membentuk komite audit. Keberadaan komite audit sangat penting bagi pengelolaan perusahaan. Komite audit merupakan komponen baru dalam sistem pengendalian perusahaan. Selain itu komite audit dianggap sebagai penghubung antara pemegang saham dan dewan komisaris dengan pihak manajemen dalam menangani masalah pengendalian.

Penelitian Veronica dan Utama (2005) dalam Rahmawati \& Baridwan (2006) menguji pengaruh keberadaan komite audit dalam perusahaan terhadap manajemen laba. Penelitian tersebut melaporkan bahwa variabel keberadaan komite audit tidak berpengaruh terhadap manajemen laba perusahaan. Hal tersebut berarti keberadaan komite audit tidak mampu mengurangi manajemen laba yang terjadi di perusahaan. Sedangkan penelitian Nasution dan Dody (2007) menguji pengaruh keberadaan komite audit dalam perusahaan terhadap manajemen laba. Penelitian tersebut melaporkan bahwa variable keberadaan komite audit berpengaruh tehadap manajemen laba perusahaan. Hal tersebut berarti keberadaan komite audit mampu mengurangi adanya manajemen perusahaan yang terjadi di perusahaan. Dari penelitian di atas maka hipotesis dalam penelitian ini adalah:

$\mathrm{H}_{3:} \quad$ Komite Audit berpengaruh terhadap manajemen laba

\section{Ukuran Perusahaan dan Manajemen Laba}

Dari pengujian Veronica dan Utama (2005) dalam Rahmawati \& Baridwan (2006) dilaporkan variabel yang berpengaruh signifikan terhadap besaran manajemen laba adalah ukuran perusahaan. Makin besar ukuran perusahaan, makin kecil tindak manajemen labanya. Rahmawati dan Baridwan (2006) menunjukkan bahwa ukuran perusahaan yang diukur dengan menggunakan kapitalisasi pasar berpengaruh signifikan positif terhadap manajemen laba perusahaan. Ini menunjukkan bahwa manajer perusahaan besar mendapat insentif yang lebih ketika dia melakukan manajemen laba demi mengurangi kos politisnya

Semakin besar ukuran perusahaan, biasanya informasi yang tersedia untuk investor dalam pengambilan keputusan sehubungan dengan investasi dalam saham perusahaan tersebut semakin banyak. Albrecth \& 
Richardson (1990) dalam Lee \& Choi (2002) dalam Rahmawati \&Baridwan (2006) menemukan bahwa perusahaan yang lebih besar kurang memiliki dorongan untuk melakukan perataan laba dibandingkan perusahaanperusahaan kecil karena perusahaan besar dipandang lebih kritis oleh pihak luar. Karena itu, diduga bahwa ukuran perusahaan mempengaruhi besaran pengelolaan laba perusahaan, dimana jika pengelolaan laba tersebut oportunis maka semakin besar perusahaan semakin kecil pengelolaan laba (berhubungan negatif) tapi jika pengelolaan laba efisien maka semakin besar ukuran perusahaan semakin tinggi pengelolaan labanya (berhubungan positif).

$\mathrm{H}_{4} \quad$ : Ukuran perusahaan berpengaruh terhadap manajemen laba

\section{Kepemilikan Manajerial dan Manajemen laba}

Shleifer dan Vishny (1986) dalam Morck et al. (1988) dalam Rahmawati \& Baridwan (2006) menyatakan bahwa kepemilikan saham yang besar dari segi nilai ekonomisnya memiliki insentif untuk memonitor. Secara teoritis ketika kepemilikan manajemen rendah, maka insentif terhadap kemungkinan terjadinya perilaku oportunistik manajer akan meningkat. Kepemilikan manajemen terhadap saham perusahaan dipandang dapat menyelaraskan potensi perbedaan kepentingan antara pemegang saham luar dengan manajemen (Jansen dan Meckling, 1976) dalam Rahmawati \& Baridwan (2006). Sehingga permasalahan keagenen diasumsikan akan hilang apabila seorang manajer adalah juga sekaligus sebagai seorang pemilik. Dari penelitian diatas maka hipotesis dalam penelitian ini adalah:

$\mathrm{H}_{5} \quad$ : Kepemilikan Manajerial berpengaruh terhadap manajemen laba

\section{METODE PENELITIAN}

\section{Populasi dan Sampel}

Populasi yang dijadikan obyek penelitian dalam penelitian ini adalah seluruh perusahaan jasa yang terdaftar dalam Bursa Efek Indonesia selama periode 2005-2007. Teknik pengambilan sampel dilakukan secara purposive sampling dengan tujuan untuk mendapatkan sampel yang representif sesuai dengan kriteria yang ditentukan. Adapun kriteria yang digunakan untuk memilih sampel adalah sebagai berikut: pertama, Perusahaan jasa yang terdaftar di Bursa Efek Indonesia selama tahun 2005-2007, kedua, Perusahaan yang telah mempublikasikan laporan keuangan auditor tahunan untuk periode 31 Desember dan dinyatakan dalam rupiah (Rp). Ketiga, Data yang tersedia lengkap (data secara keseluruhan tersedia pada publikasi periode 31 Desember 2005-2007)

\section{Definisi Operasional Variabel}

Variabel yang digunakan dalam penelitian ini adalah: Komposisi dewan komisaris, Ukuran dewan komisaris, Keberadaan komite audit, Ukuran perusahaan, Kepemilikan Manajerial dan Manajemen laba. Variabel Komposisi dewan komisaris merupakan variable independen, yaitu dengan menggunakan persentase jumlah dewan komisaris independen terhadap jumlah total komisaris yang ada dalam susunan dewan komisaris 
perusahaan sampel.

Variable Ukuran dewan komisaris diukur dengan menggunakan jumlah total anggota dewan komisaris, baik yang berasal dari internal perusahaan maupun dari eksternal perusahaan sampel. Keberadaan komite audit Merupakan variable dummy, bila perusahaan sampel memiliki komite audit maka dinilai 1, dan jika sebaliknya maka dinilai 0. Variable Ukuran perusahaan ini diukur dengan menggunakan logaritma total asset perusahaan sampel. Kepemilikan manajerial adalah persentase besarnya jumlah saham yang dimiliki manajemen dari total saham yang beredar.

Sedangkan variabel manajemen laba menurut Bartov et.al. (2000) dalam Aloysia Yanti Ardiati (2005) dalam Rahmawati \& Baridwan (2006) mengevaluasi kemampuan 7 model estimasi accrual dalam mendeteksi manajemen laba dan menyimpulkan bahwa model Jones merupakan model yang lebih baik dibanding model time-series. Total Accrual diestimasi dengan model cross-sectional Jones Model sebagai fungsi property, plant, dan equipment (PPE), serta perubahan pendapatan dan piutang bersih.

TACC $_{\mathrm{j}, \mathrm{T}}$

$$
=\mathrm{EBXT}_{\mathrm{j}, \mathrm{t}}-\mathrm{OCF}_{\mathrm{j}, \mathrm{t}}
$$

$$
=\frac{T A C C_{j, t}}{T A_{j, t-1}}=\mathrm{a}_{1}\left(\frac{1}{T A_{j, t-1}}\right)+\mathrm{a}_{2}\left(\frac{\Delta R E V_{j, t}-\Delta R E C_{j, t}}{T A_{j, t-1}}\right)+\mathrm{a}_{3}\left(\frac{P P E_{j, t}}{T A_{j, t-1}}\right)+\mathrm{e}_{j, t}
$$

$\operatorname{NDACC}_{\mathrm{j}, \mathrm{t}} \quad=\mathrm{a}_{1}\left(\frac{1}{T A_{j, t-1}}\right)+\mathrm{a}_{2}\left(\frac{\Delta R E V_{j, t}-\Delta R E C_{j, t}}{T A_{j, t-1}}\right)+\mathrm{a}_{3}\left(\frac{P P E_{j, t}}{T A_{j, t-1}}\right) \ldots$ (3)

DACC $_{\mathrm{j}, \mathrm{t}} \quad=\left(\mathrm{TACC}_{\mathrm{j}, \mathrm{t}} / \mathrm{TA}_{\mathrm{j}, \mathrm{t}-\mathrm{I}}\right)-\mathrm{NDACC}_{\mathrm{j}, \mathrm{t}} \ldots \ldots \ldots \ldots \ldots \ldots \ldots \ldots \ldots \ldots \ldots \ldots$

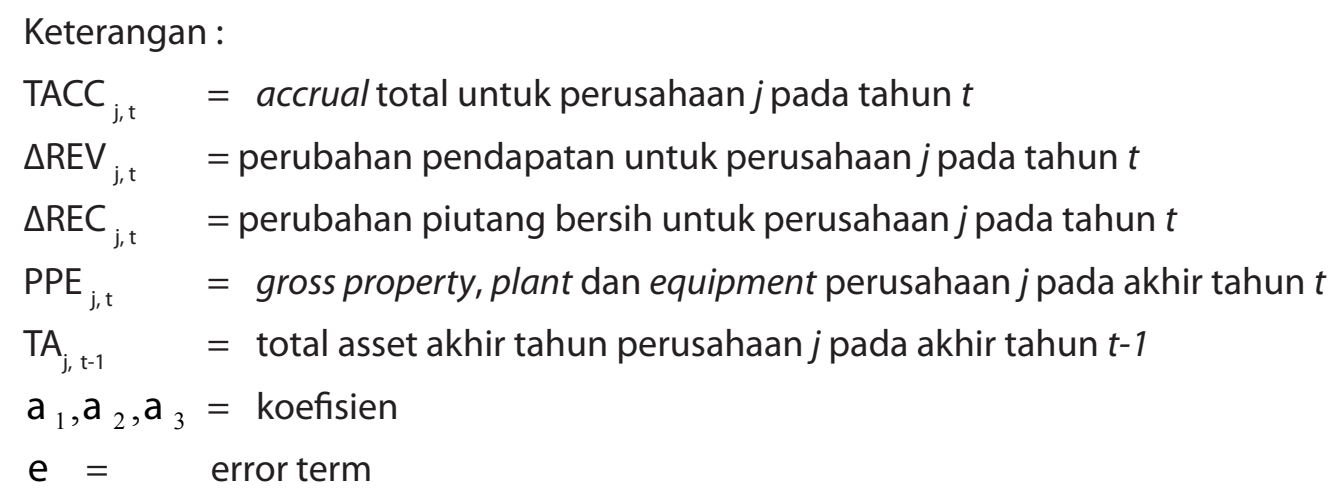

\section{Metode Analisis Data}

Dalam menguji hipotesis yang diajukan dalam penelitian ini, peneliti menggunakan metode analisis regresi berganda. Berdasarkan hipotesis yang diajukan di atas, maka model yang digunakan untuk melihat pengaruh corporate governance terhadap manajemen laba adalah sebagai berikut:

$D_{\text {it }} \quad: a+\beta 1 K D K+\beta 2$ UDK $+\beta 3 \mathrm{KKA}+\beta 4 \mathrm{UKP}+\beta 5 \mathrm{KP}+\varepsilon$ 


$\begin{array}{lllll}\text { a } & \text { : konstanta } & \beta & : & \text { koefisien regresi } \\ \text { DA }_{\text {it }} & : \text { discretionary accruals } & \text { KDK } & : & \text { komposisi dewan komisaris } \\ \text { UDK } & : \text { ukuran dewan komisaris } & \text { KKA } & : & \text { keberadaan komite audit } \\ \text { UKP } & : \text { ukuran perusahaan } & \text { KP } & : & \text { Kepemilikan Manajerial } \\ \varepsilon & : \text { koefisien error } & & & \end{array}$

\section{HASIL DAN PEMBAHASAN}

\section{Hasil Penelitian}

Setelah dilakukan pengujian dan data telah memenuhi ke empat uji asumsi klasik, maka pengujian lebih lanjut dilakukan melalui uji regresi berganda. Hasil pengujian hipotesis dengan regresi disajikan pada tabel berikut ini. Berdasarkan perhitungan regresi berganda dengan versi SPSS 17.00 diperoleh hasil sebagai berikut :

Hasil pengujian model regresi diperoleh nilai signifikansi sebesar 0,015 . Maka sig $F(0,015)<a(0,05)$, maka dapat disimpulkan bahwa secara bersama-sama variabel komposisi dewan komisaris, ukuran dewan komisaris, komite audit, ukuran perusahaan, dan kepemilikan manajerial berpengaruh terhadap manajemen laba. Dengan demikian model regresi adalah baik. Untuk menunjukkan apakah variabel bebas secara individu mempunyai pengaruh yang signifikan terhadap variabel terikat maka digunakan uji t (uji parsial).

\section{Pembahasan}

Hasil penelitian menunjukkan bahwa untuk variabel komposisi dewan komisaris memiliki pengaruh yang signifikan terhadap manajemen laba. Hasil tersebut ditunjukkan dengan nilai signifikansi sebesar 0,002 atau kurang dari batas signifikansi 0,05. Dari penjelasan tersebut, dapat disimpulkan bahwa penelitian ini berhasil membuktikan bahwa komposisi dewan komisaris berpengaruh secara signifikan terhadap manajemen laba yang pertama disebabkan bahwa komisaris independen telah efektif dalam menjalankan tanggung jawabnya mengawasi kualitas pelaporan keuangan demi membatasi manajemen laba di perusahaan. Hal tersebut disebabkan karena dengan makin banyak anggota komisaris independen maka proses pengawasan yang dilakukan dewan ini makin berkualitas dengan makin banyaknya pihak independen dalam perusahaan yang menuntut adanya transparasi dalam pelaporan keuangan perusahaan. Hasil ini mendukung penelitian Beasley (1996), Wedari (2004) dalam Rahmawati \& Baridwan (2006) dan Wilopo (2004) yang menyatakan komposisi dewan komisaris berpengaruh terhadap manajemen laba.

Hasil penelitian menunjukkan bahwa untuk variabel ukuran dewan komisaris memiliki pengaruh yang signifikan terhadap manajemen laba. Hasil tersebut ditunjukkan dengan nilai signifikansi sebesar 0,018 atau kurang dari batas signifikansi 0,05. Dari penjelasan tersebut, dapat disimpulkan bahwa penelitian ini berhasil membuktikan bahwa ukuran dewan komisaris berpengaruh secara signifikan terhadap manajemen laba yang dilakukan dalam perusahaan jasa, kondisi ini disebabkan karena perusahaan yang memiliki dewan komisaris dalam jumlah banyak maka tindak manajemen laba yang dilakukan perusahaan juga semakin banyak. Kondisi 
tersebut dapat disebabkan karena sulitnya koordinasi antar anggota dewan tersebut dan hal ini menghambat proses pengawasan yang harusnya menjadi tanggung jawab dewan komisaris. Hasil ini mendukung penelitian Midiastuty dan Machfoedz (2003), yang menyatakan ukuran dewan komisaris berpengaruh terhadap manajemen laba perusahaan.

Hasil penelitian menunjukkan bahwa untuk variabel komite audit tidak memiliki pengaruh yang signifikan terhadap manajemen laba. Hasil tersebut ditunjukkan dengan nilai signifikansi sebesar 0,236 atau lebih dari batas signifikansi 0,05. Dari penjelasan tersebut, dapat disimpulkan bahwa penelitian ini Komite audit tidak berpengaruh terhadap manajemen laba, yang pertama kondisi ini terjadi karena komite audit dibentuk oleh dewan komisaris, sehingga dalam tugasnya kurang berpengaruh terhadap manajemen laba. Kedua dalam perusahaan jasa kurang menjalankan tugas sebagaimana mestinya dalam melakukan pengawasan terhadap perusahaan dengan menjunjung prinsip corporate governance, transparasi, fairness, tanggung jawab, dan akuntabilitas (NCCG, 2001). Ketiga, pada perusahaan jasa belum sepenuhnya membentuk komite audit dalam perusahaanya. Hasil penelitian ini mendukung penelitian yang dilakukan oleh Veronika dan Utama (2005) dalam Rahmawati \& Baridwan (2006), yang menyatakan komite audit tidak berpengaruh terhadap manajemen laba.

Hasil penelitian ini bertolak belakang dengan penelitian sebelumnya hal ini dikarenakan pada objek penelitian terdahulu menggunakan perusahaan perbankan dimana perusahaan telah menjalankan mekanisme corporate governance yang telah ditetapkan oleh NCCG. Selain itu perusahaan perbankan telah menerapkan komite audit yang diatur dalam Kep-29/PM/2004 yang mewajibkan perusahaan untuk membentuk komite audit. Komite audit dalam perusahan perbankan telah menjalankan tugas komite audit salah satunya menjaga kerahasiaan dokumen, data, dan rahasia perusahaan.

Hasil penelitian menunjukkan bahwa untuk variabel ukuran perusahaan tidak memiliki pengaruh yang signifikan terhadap manajemen laba. Hasil tersebut ditunjukkan dengan nilai signifikansi sebesar 0,222 atau lebih dari batas signifikansi 0,05. Dari penjelasan tersebut, dapat disimpulkan bahwa penelitian ini ukuran perusahaan tidak berpengaruh terhadap manajemen laba. yang pertama karena ukuran perusahaan dalam sampel penelitian ini memiliki ukuran yang berbeda-beda, seperti perusahaan transportasi memiliki ukuran perusahaan yang besar dibandingkan perusahaan asuransi yang memiliki nilai aktiva atau ukuran perusahaan yang kecil. Kondisi tersebut memungkinkan bahwa ukuran perusahaan tidak mampu menjelaskan manajemen laba. Menurut teori perusahaan yang berukuran besar memiliki basis pemegang kepentingan yang lebih luas, sehingga berbagai kebijakan perusahaan besar akan berdampak lebih besar terhadap kepentingan publik dibandingkan dengan perusahaan kecil. Terdapat dua pandangan mengenai ukuran perusahaan pertama Perusahaan yang besar lebih diperhatikan oleh masyarakat sehingga mereka akan lebih berhati-hati dalam melakukan pelaporan keuangannya, sehingga berdampak perusahaan tersebut melaporkan kondisinya lebih akurat. Kedua dimana perusahaan kecil lebih memiliki kesempatan untuk memanipulasi laba dalam perusahaan. Hasil ini tidak mendukung penelitian Veronica dan Utama (2005) dalam Rahmawati \& Baridwan (2006), Rahmawati dan Baridwan (2006), yang menyatakan ukuran perusahaan berpengaruh terhadap manajemen laba. 
Hasil penelitian menunjukkan bahwa untuk variabel kepemilikan manajerial tidak memiliki pengaruh yang signifikan terhadap manajemen laba. Hasil tersebut ditunjukkan dengan nilai signifikansi sebesar 0,581 atau lebih dari batas signifikansi 0,05. Kepemilikan manajerial tidak berpengaruh terhadap manajemen laba. Namun penelitian ini tidak berhasil mendukung penelitian sebelumnya Midiastuty dan Machfoedz (2003) yang mengatakan kepemilikan manajerial berpengaruh positif terhadap manajemen laba. Hal ini di karenakan bahwa penelitian tersebut menyatakan bahwa kualitas laba meningkat ketika kepemilikan manajerial tinggi. Sementara pada penelitian ini disebabkan mungkin kepemilikan manajerial dalam penelitian ini terlalu kecil, yaitu rata-rata 10,13 persen, sehingga kurang berperan dalam pengambilan keputusan tentang manajemen perusahaan, termasuk di dalamnya manajemen laba. Secara teoritis ketika kepemilikan manajemen rendah, maka insentif terhadap kemungkinan terjadinya perilaku oportunistik manajer akan meningkat. Selain itu rendahnya kepemilikan saham manajerial dapat memberikan pengaruh terhadap proses penyusunan laporan keuangan sehingga laporan laba mempunyai kekuatan yang kurang responsif yang dapat memberikan reaksi negatif bagi pihak-pihak yang berkepentingan seperti pemegang saham dan pelaku pasar modal pada umumnya.

\section{SIMPULAN}

Berdasarkan hasil penelitian yang telah dilakukan pada perusahaan jasa periode penelitian 2005 2007 tentang pengaruh corporate governance terhadap manajemen laba, maka dapat diajukan beberapa kesimpulan sebagai berikut : pertama, Komposisi dewan komisaris, ukuran dewan komisaris berpengaruh terhadap manajemen laba, hal ini dibuktikan dengan signifikansi kurang dari batas 0,05. kedua, Komite audit, ukuran perusahaan, dan kepemilikan manajerial tidak berpengaruh manajemen laba, hal ini dibuktikan denga nilai signifkansi lebih dari batas 0,05, dan ketiga Komposisi dewan komisaris, ukuran dewan komisaris, Komite audit, ukuran perusahaan, dan kepemilikan manajerial berpengaruh secara signifikan terhadap manajemen laba.

\section{Saran}

Saran dalam penelitian ini adalah pertama, pihak investor bisa menggunakan variabel komposisi dewan komisaris dan ukuran dewan komisaris untuk melihat apakah perusahaan melakukan manajemen laba atau tidak, sebelum investor akan menanamkan modalnya di perusahaan tersebut, karena ini akan mempengaruhi dan pada akhirnya akan mempengaruhi tingkat pengembalian. Kedua, Penelitian selanjutnya bisa menambah variabel penelitian seperti kualitas auditor, profitabilitas, leverage agar lebih bisa menjelaskan manajemen laba.

\section{DAFTAR REFERENSI}

Beasley, Mark S., 1996. "An Empirical Analysis of The Relation Between The Board of Director Composition and Financial Statement Fraud." The Accounting Review Volume 71, No 4, Oktober : 443-465

Bernhart, S. W. and Rosenstein S. 1998. "Board Composition, Managerial Ownership, and Firm Performance: An Empirical Analysis." Financial Review, 33, p. 1-16 
Imam Ghozali, 2005, "Aplikasi Analisis Multivariate Dengan Program SPSS" Badan Penerbit Universitas Diponegoro.

Klein, April. 2002. "Audit Committee, Board Of Director Characteristics and Earnings Management". Journal of Accounting and Economics, Vol.33. No.3. August, p.375-400.

Midiastuty, Pratana P., dan Mas'ud Machfoed., 2003. "Analisis Hubungan Mekanisme Corporate Governance dan Indikasi Manajemen Laba." Simposium Nasional Akuntansi 6 Surabaya tanggal 16-17 Oktober 2003

Nasution dan Doddy. 2007. “Pengaruh Corporate Governance terhadap Manajemen laba pada perusahaan Perbankan Indonesia." Simposium Nasional Akuntansi 10 Makassar tanggal 26-28 Juli 2007.

National Committee on Corporate Governance (NCCG).2001. Indonesia Code for Good Corporate Governance

Nuryam., (2008)." Pengaruh Konsentrasi Kepemilikan, Ukuran Perusahaan, dan Mekanisme Corporate Governance terhadap Manajemen Laba"., Simposium Nasional Akuntansi (SNA) Pontianak.

Rahmawati \& Baridwan. 2006. Model Penelitian Manajemen Laba pada Industri Perbankan Publik di Indonesia dan Pengaruhnya Terhadap Kinerja Perbanakan. Artikel yang Dipresentasikan pada Seminar Bulanan Jurusan Akuntansi FE-UNS tanggal 27 Mei 2006

Santoso, Singgih . 2000. Buku Latihan SPSS Statistik Parametrik. Jakarta: PT.Elex Media Komputindo

Schipper, Khaterine and Linda Vincent. 2003. “Earnings Quality”.AccountingHorizons,Vol.17. Supplement, p.97110.

Scott, William R., 2000. "Financial Accounting Theory." Second edition. Canada: Prentice Hall.

Setiawan, Lilis dan Ainum Na'im. 2001. Bank Health Evolution by Bank Indonesia and Earnings Management in Banking Industry . Gajah Mada Internasional Journal of Business Volume 3 No 2 May: 159-176

Siallagani, Hamongan dan Mas'ud Machfoedz (2006). “Mekanisme Corporate Governance, Kualitas Laba dan Nilai Perusahaan", Simposium Nasional Akuntansi 9 Padang tanggal 23-26 Desember 2006

Shleifer, A. and R.W. Vishny. 1997. "A Survey of Corporate Governance." Journal of Finance, Vol.52. No.2. June, p.737-783.

Surfiah, 2001, "Study Tentang Indikasi Unsur Manajemen Laba pada Laporan Keuangan Perusahaan Publik di Indonesia", Jurnal Akuntansi dan Auditing, Vol .5/ No.1/Juni.

Utama, Sidharta, dan F. Leonardo Z. 2006. :Audit Committee Composition. Control of Majority Shareholder and Their Impact on Audit Committee Efectiveness:Indonesia Evidence." Jurnal Riset Akuntansi Indonesia Volume 9 No 1 Januari : 21-34

Wilopo.2004. "The Analysis of Relationship of Independent Board of Directors, Audit Committee, Corporate Performance, and Discretionary Accruals." Ventura Volume 7 No.1 April : $73-83$ 
Tabel 1

Hasil Uji Signifikansi Secara Simultan

ANOVA

\begin{tabular}{|ll|r|r|r|r|r|}
\hline & & & & & \\
\hline 1 & Sum of & & & & \\
& Regression & .110 & 5 & .022 & 3.097 & $.015^{\mathrm{a}}$ \\
& Total & .439 & 62 & .007 & & \\
& .548 & 67 & & & \\
\hline
\end{tabular}

Sumber : Data yang diolah, 2010

Tabel 2

Hasil Uji t

Coefficients $^{\mathrm{a}}$

\begin{tabular}{|c|c|c|c|c|c|c|}
\hline & \multicolumn{2}{|c|}{ Unstandardized } & Standardized & & \\
\hline 1 & (Constant) & -.043 & .093 & & -.459 & .648 \\
\hline & $\begin{array}{l}\text { komposisi dewan } \\
\text { komisaris }\end{array}$ & .254 & .079 & .430 & 3.221 & .002 \\
\hline & ukuran dewan komisaris & .016 & .006 & .375 & 2.429 & .018 \\
\hline & komite audit & -.029 & .025 & -.145 & -1.198 & .236 \\
\hline & ukuran perusahaan & -.008 & .006 & -.185 & -1.234 & .222 \\
\hline & kepemilikan manajerial & -.028 & .051 & -.067 & -.555 & .581 \\
\hline
\end{tabular}

Sumber : Data yang diolah, 2010 